\title{
Weather and market specificities in the regional transmission of renewable energy price effects
}

\author{
Nuno Carvalho Figueiredo a, b, *, Patrícia Pereira da Silva ${ }^{\text {b, c }}$, Derek Bunn ${ }^{\text {d }}$ \\ ${ }^{a}$ EFS Initiative, University of Coimbra, Sustainable Energy Systems - MIT-P, Coimbra, Portugal \\ b INESCC, Coimbra, Portugal \\ ${ }^{\mathrm{c}}$ Faculty of Economics, University of Coimbra, Coimbra, Portugal \\ ${ }^{\mathrm{d}}$ Department of Management Science and Operations, London Business School, Regent's Park, London NW1 4SA, UK
}

\section{A R T I C L E I N F O}

\section{Article history:}

Received 16 April 2016

Received in revised form

11 July 2016

Accepted 30 July 2016

\section{Keywords:}

Electricity

Market integration

Wind energy

Weather

Prices

\begin{abstract}
A B S T R A C T
This study is motivated by the observation that the effects of renewable energy output variations across several integrated power markets are likely to be complicated by price arbitrage and weather dynamics. Wind in particular has supply side effects when associated with substantial generating facilities, but also demand side influences when associated with extreme weather conditions. To unravel these effects, daily electricity prices and the weather variables wind, temperature and their interaction (wind chill) in the Central-West Europe coupled market were analysed from 2007 to the end of 2014 by means of vector autoregressions. The spillover effects were found to be quite subtle. Despite efficient price arbitrage, it is not the case that daily wind output shocks diffuse uniformly across all markets, or that the largest generator of wind energy creates the most significant spillovers or that high wind conditions necessarily lead to lower prices. Market specificities matter and are important for operational prediction and weather risk hedging.
\end{abstract}

(C) 2016 Elsevier Ltd. All rights reserved.

\section{Motivation}

European policy to increase market integration in wholesale electricity trading has been intensively pursued since the vision of a single energy market emerged in the 1990s. Whilst the need for more interconnectors and harmonisation of trading was initially motivated by the pursuit of economic efficiency and greater competition, policy-makers have been encouraged further in this direction by the emergence of substantial amounts intermittent renewable generation. The rapid rise in generation from wind and solar in particular, again motivated primarily by policy, raises concerns about security of supply in the longer term and also efficient system balancing in the short term, both of which appear to be remedied to some extent by more regional interconnectivity. Moreover, with the renewable energy sources (RES) capacity forecast to grow substantially, ENTSO-E (2015) [1] emphasise the growing importance of cross-border electricity flows in order to maintain generation adequacy. In this context, therefore, it is easy

\footnotetext{
* Corresponding author. EFS Initiative, University of Coimbra, Sustainable Energy Systems - MIT-P, Coimbra, Portugal.

E-mail address: nuno.figueiredo@portugen.com (N.C. Figueiredo).
}

to understand why there has been extensive research on modelling the progress of market integration in electricity prices, expressed both in terms of price convergence and the dynamics of shock transmissions.

However, the inter-regional price effects of large volumes of renewable energy are awkward to clarify, and the impact of weather has generally been under-specified in the market integration studies. Large volumes of renewable energy are weather induced, and their local price effects might transmit to neighbouring markets, arbitrage permitting, but weather conditions are also correlated across regions. Thus, even without interconnections, common weather conditions induce price co-movements. Furthermore, weather affects both the demand and supply sides of the markets in different ways and these will be idiosyncratic to the consumption drivers and generation technology mixes in each market. Unravelling these confounding factors is particularly important for system operations and price risk management. For example, the use of weather insurance, derivatives or other hedges require explicit models of price transmission between regions that distinguishes arbitrage effects from weather spillovers.

The objective of this paper is therefore to undertake a detailed econometric analysis of price transmission in the daily coupled 
wholesale market of Central-West Europe (CWE) taking explicit account of renewable energy generation and with a focus upon the particular weather variables wind, temperature and their interaction (wind chill). The next section provides a review of relevant background research, followed by summaries of the European Union initiatives for market integration, renewable energies and the emergence of the CWE market. The data and analysis follow. On the basis of results from some large vector-autoregression models in section, we offer some new insights.

\section{Background research}

Weather conditions are essential variables for demand forecasting and numerous methods have developed over many years to model ambient temperatures in various forms, wind speed with its associated wind chill effects, humidity, cloud coverage and others. Maximum and minimum ambient temperatures were used for demand forecasting in Italy by Sforna (1995) [2], whilst Islam et al. (1995) [3] in Muscat used selected climate variables according to their correlation with electricity demand (maximum temperature, maximum and average relative humidity, wind speed, duration of sunshine, global radiation, degree days and a comfort index). Correlation of electricity demand and climate variables was also used to select adequate input variables by Santos et al. (2007) [4] and Amjady and Keynia (2009) [5]. Robinson (1997) [6] simply used a daily average ambient temperature in demand forecasting. Sailor and Muñoz (1997) [7] used in addition to ambient temperature, relative humidity (in the form of enthalpy latent days) and wind speed, all population-weighted. Taylor (2003) [8] improved on the existing use by the UK National Grid of single point weather forecasts, by using weather ensembles. A population-weighted mean daily outdoor temperature was used by Pardo et al. (2002) [9] to calculate heating and cooling degree days (HDDs and CDDs) for a demand model to account for the influence of temperatures on demand. The use of HDD, CDD and the mean relative humidity was also used by Mirasgedis et al. (2006) [10] in statistical models for the daily and monthly electricity demand prediction for Greece. Bessec and Fouquau (2008) [11] assessed the influence of temperature on demand across Europe and found a non-linear relation with a clear heating effect. Moreover, the cooling effect was more important in the south European countries with a clear U-shape relation. Suganthi and Samuel (2012) [12] performed a comprehensive review of the types of models used for demand forecasting, most of them involving climate conditions as explanatory variables. A study of climate determinants on demand was carried out for Italy [13] highlighting the importance of the increasing installation of air conditioning in the electricity demand since 2003.

To the extent that price forecasts depend upon demand, all of these weather effects pass through implicitly $[14,15]$. The introduction of weather determinants on electricity price forecasting is explicitly mentioned by many researchers [16,17]. However, Wu and Shahidehpour (2010) [18] suggest that weather variables might cause overfitting and model inaccuracies. Nevertheless, Weron and Misiorek (2008) [19] used ambient temperatures in the electricity price forecasting model for Nord Pool. Comprehensive reviews of electricity spot price modelling are made by Higgs (2008) [20], Aggarwal et al. (2009) [21] and by Weron (2014) [22], which report the use of ambient temperature as an input variable. Furthermore, Higgs and Worthington (2008) [23], Christensen et al. (2012) [24] and Zachmann (2013) [25] recognise that, in their multi-state models, the transition probabilities and electricity price spikes are, or may be, weather dependent. Wind power forecasts are used in electricity price forecasting by Cruz et al. (2011) [26], Jónsson et al. (2013) [27] and Ziel et al. (2015) [28] with appealing results, demonstrating model performance improvements. The latter also included solar power in the electricity price forecasting of Germany and Austria. Additionally, Keles et al. (2013) [29] introduces a selfcontained wind power forecast, which is then used in the electricity price forecast. A summary of the analysed literature involving weather variables is provided in Table 6 Appendix A.

Regarding the interconnection of regional electricity markets, De Vany \& Walls (1999) [30] looked at market integration across eleven regions in the western United States using spot market electricity prices from 1994 to 1996, aggregated by peak and offpeak values, as did Park, Mjelde, \& Bessler (2006) [31]. In Australia, Worthington, Kay-Spratley \& Higgs (2005) [32] examined the integration of the Australian National Electricity Market, but found poor integration. Later, Higgs (2009) [33] also assessed the Australian National Electricity Market in terms of the level of integration, examining the inter-relationships of wholesale spot electricity prices among four markets, finding by then that the highly interconnected markets have higher conditional correlations. In Europe several studies have looked at market integration (e.g. Refs. [34,35]). Econometric methods have been based upon on correlations, cointegration analysis, fractional cointegration, exploratory data analysis of price differences variability, vector autoregressive (VAR), vector error correction models (VECM), Granger-causality, principal components and impulse response analyses. The Central-West Europe (CWE) region was found to be integrated in these studies and increasingly so over time. Lately the authors specified a number of VAR models to evaluate the effects of the introduction of the market coupling mechanism between the trilateral market (Belgium, France and the Netherlands) and Germany, leading to the conclusion that this has created an apparent smoothing of the responses to innovations of the integrated CWE markets [35].

\section{Market integration, renewable energies and the CWE}

Directive 90/547/EEC on the transit of electricity through transmission grids [36] aligned to Directive 90/377/EEC concerning the transparency of gas and electricity prices charged to industrial end-users [37], provided the first steps for the creation of the internal European electricity market. Later, Directives 96/92/EC, 2003/54/EC and 2009/72/EC established harmonised rules for the various electricity markets [38,39]. Regulatory agencies were created throughout the European Member States in order to transpose and implement the local corresponding laws and regulations. The main regulatory functions aimed to: provide licencing, perform monitoring of activities, set and implement tariffs, and to protect customers [40]. In 2006, market integration in Europe was still far from being achieved [41], and this led the European Commission to foster an Agency for the Cooperation of Energy Regulators (ACER) which in turn launched seven Electricity Regional

Table 1

Indicative values for NTC in MW

\begin{tabular}{llllll}
\hline To & From & & & & \\
\cline { 2 - 5 } & BE & DE & FR & LU & NL \\
\hline BE & & & 3400 & & 2400 \\
{$[19,500]^{\mathrm{a}}$} & & & 2700 & 3000 \\
$\mathrm{DE}$ & & & & \\
{$[163,800]^{\mathrm{a}}$} & 2300 & 3200 & & \\
FR & & & & \\
{$[125,900]^{\mathrm{a}}$} & & 980 & & \\
$\mathrm{LU}$ & & & & \\
{$[1800]^{\mathrm{a}}$} & 2400 & 3850 & & \\
$\mathrm{NL}$ & & & & \\
{$[28,200]^{\mathrm{a}}$} & & & & \\
\hline
\end{tabular}

\footnotetext{
a Installed Electricity Generation Capacity in MW [45].
} 


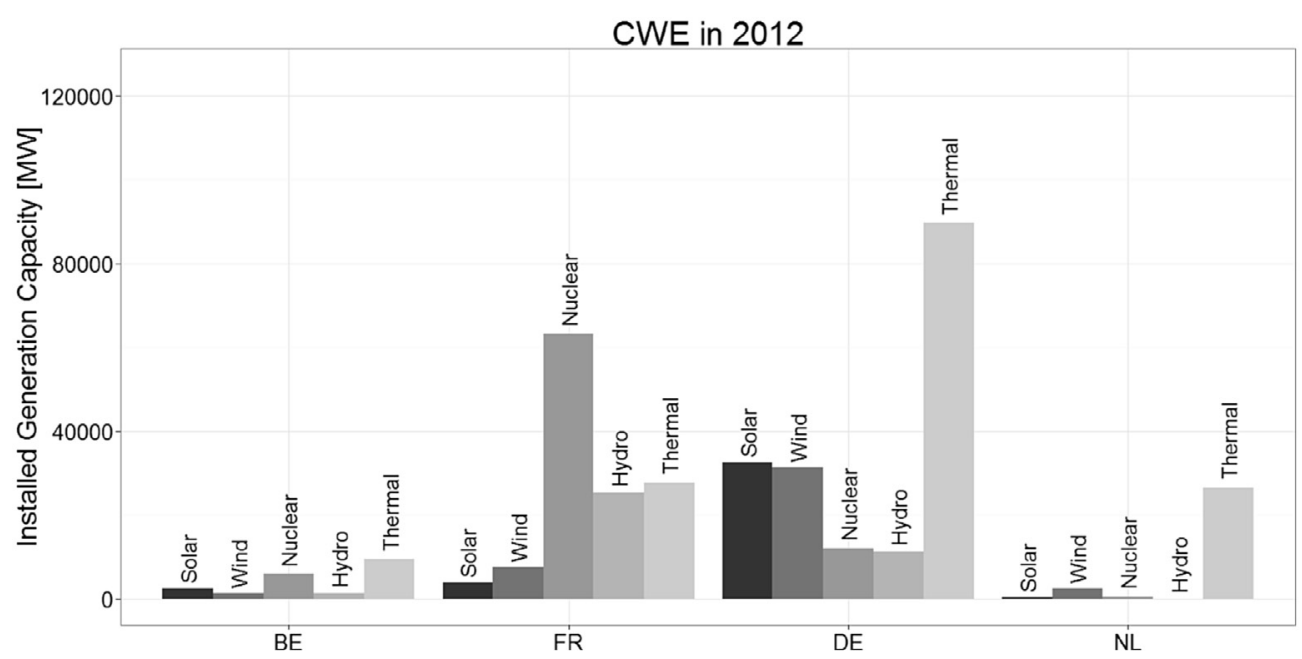

Fig. 1. CWE installed generation capacities in 2012.
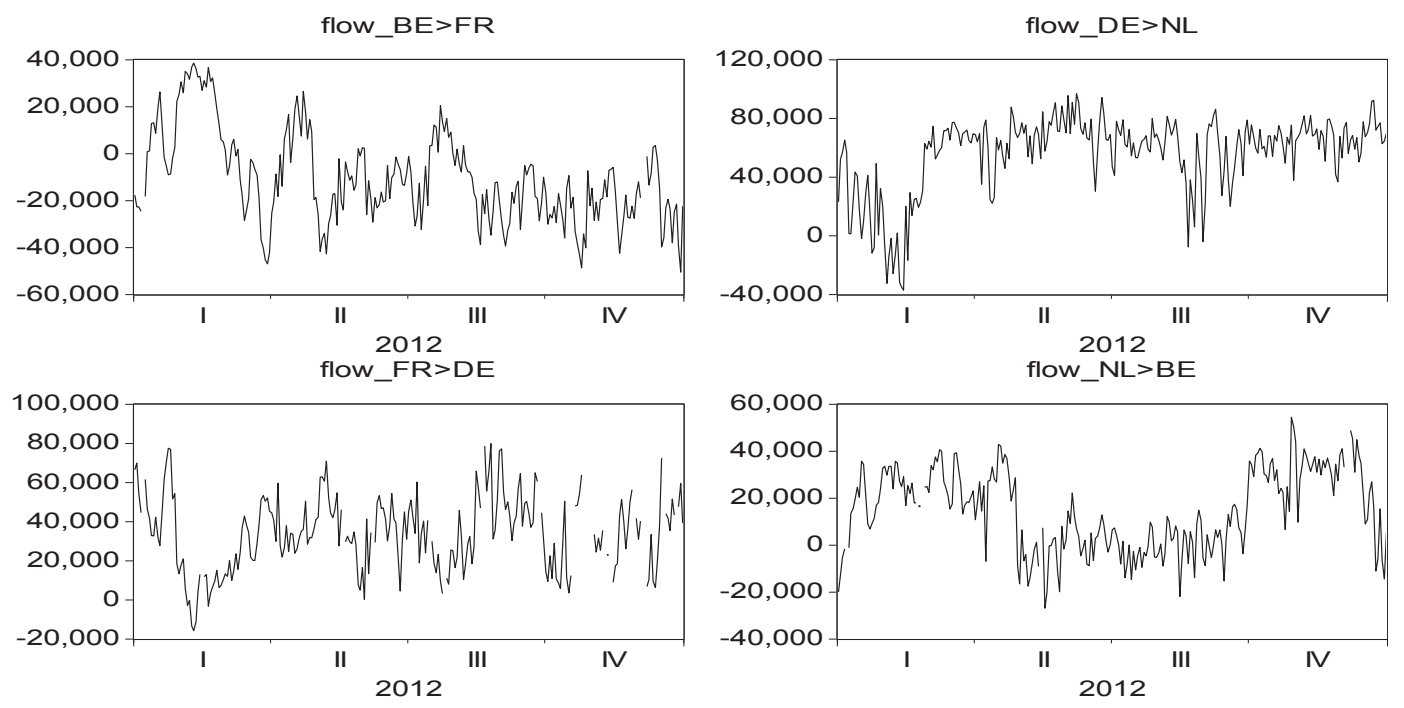

Fig. 2. CWE electricity cross-border flows (flow) [MWh] in CWE in 2012 (Belgium - BE, France - FR, Germany - DE and the Netherlands - NL).

Initiatives [42,43], one of which, the Central West (Belgium, France, Germany, Luxembourg, Netherlands) is the focus here.

In Table $1[44,45]$ the Net Transfer Capacities (NTC) and respective installed electricity generation capacities declared between the CWE countries are shown. Note the relatively small NTC between France and Germany compared to their sizes of installed electricity generation capacity.

Almost simultaneously with the initiatives for market integration, Directives 2001/77/EC and 2009/28/EC, called for the promotion of electricity generation by RES in Europe [46,47]. The aim was to reduce dependency on imported fossil fuels for both security and low carbon reasons. The large deployment of RES generation in Europe was achieved through a programme of strong financial support mechanisms [48-50], including feed-in tariffs, feed-in premia, fiscal incentives, tax exemptions and others. The RES electricity (RES-E) generation in Europe was 467,7 TW h in 2013 consisting of $42.4 \%$ hydroelectric, $27.4 \%$ wind, $10.4 \%$ solar, $9,9 \%$ biomass and $10 \%$ of other renewable technologies [51]. The CWE electricity markets, in particular Germany, have been prominent in this structural change and Fig. 1 displays the generating capacity mix in 2012 (excluding Luxembourg). Clearly the four countries are very different in both scale and mix.

The impact of RES-E on electricity markets has been discussed widely. Wind, for example, like any low marginal cost generation displaces higher marginal cost technologies and this "merit-order effect" is well recognised in leading to lower wholesale prices [52]. Evidently, the extent of this merit order effect will depend upon the slope of the merit order stack around the demand levels. If it is quite flat, with a lot of similar generating technology, e.g. the stack of thermal coal plant in Germany, the wind depression on prices may not show at normal times but only perhaps at low demand periods. How the wind effects may then transmit to neighbouring markets is even more complex. We analyse this process in the following sections.

\section{Transmission of renewable energy and CWE market specificities}

Whilst we expect higher renewable energy volumes in a particular market to lower prices, depending upon the slope of the supply function, how that effect spills over to neighbours will depend upon various circumstances. Thus, if the interconnector is 

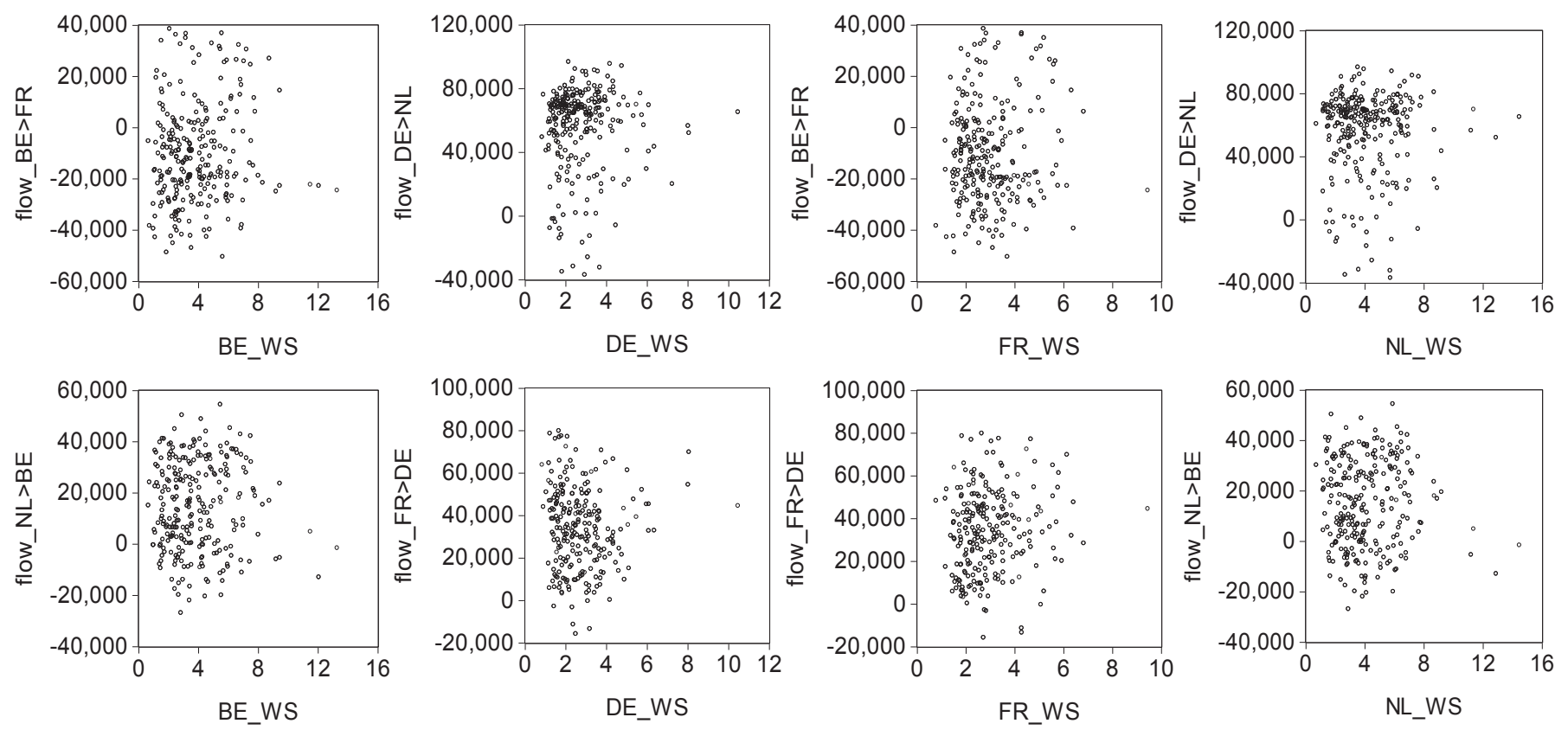

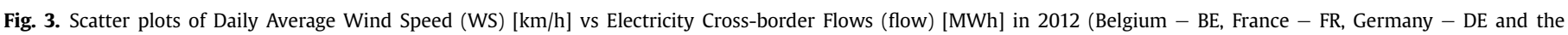
Netherlands - NL).

congested or if the price spread does not motivate arbitrage, no power will flow, and if the slope of the neighbour's supply function is too flat, or if the volumes involved are immaterial, the price changes will be minimal. Thus, we cannot simply presume that a country with a lot of wind generation will necessarily be a major influence on neighbouring prices. Likewise, we cannot expect a small country to make a substantial impact on a much larger country's prices. Furthermore, it is possible to envisage a process whereby wind volumes may not affect one country, because of a flat supply function, but may get exported and substantially reduce prices for a neighbour. And weather conditions in neighbouring countries could have counter-balancing demand side effects that induce apparently counter-intuitive spillovers. For example, high wind in one country that has relatively little wind production but a substantial amount of electric heating (e.g. France) could cause an increase demand (and hence prices) because of wind-chill [53], and so the import of wind-generated excess power from a neighbouring country (e.g. Germany) may actually appear to be correlated with higher price. To explore these and other specificities, we first look at the CWE interactions.

In Fig. 2, taken from ENTSO-E, (2015b) [54] we see that most of the cross-border export flows are from France to Germany and to Belgium, from Germany to the Netherlands, and from the Netherlands to Belgium, but they are all variable and flows do reverse. Fig. 3 shows the influence of wind speed ${ }^{1}$ on electricity cross-border flows and these scatter plots do not indicate strong correlations of cross-border flows with wind speed. ${ }^{2}$ Only flows from Germany to the Netherlands seem to be associated with higher wind speeds, but this appears to be due a few influential observations. All of which raises the question of whether there is indeed less cross-border impact of wind than expected, or whether there are confounding factors. In the next section, therefore, we estimate some vector time-series models to identify weather and

\footnotetext{
1 Daily average wind speed (in $\mathrm{km} / \mathrm{h}$ ) taken from www.wunderground.com [60].

2 Correlations between cross-border-flows and wind speed are available upon request.
}

price spillover effects and explore these interactions.

\section{Data and vector modelling}

Price data was extracted from Datastream [55] for the dayahead spot electricity prices in $€ / M W h$, except weekends, from the 1 st of November 2007 to the 31st of December 2014. We focus on peak prices (hours 9-20) since it is during high demand periods that extra transmission capacity should be valued efficiently. Fig. 4 displays the price time series, which exhibit the usual characteristics of volatility clustering and spikes [20,41,56-58]. The meanreverting nature was confirmed with Augmented Dickey-Fuller (ADF) and Phillips-Perron (PP) test statistics indicating stationarity as in Boisseleau (2004), Park et al. (2006) and Bunn and Gianfreda (2010) [31,34,59]. Daily weather data was retrieved from www.wunderground.com [60]: maximum and minimum ambient temperatures (in degrees Celsius) and average wind speed (in $\mathrm{km} /$ h) for each country of the CWE. Maximum and minimum ambient temperatures were then used to calculate Heating Degree-days ${ }^{3}$ (HDD) according to the UK Meteorological Office method [61,62]. A proxy for wind power was obtained through the product of average wind speed and installed wind power capacity. ${ }^{4}$ Also a proxy for the wind chill effect was obtained through the product of wind speed and HDD. In previous work [63], the authors established that cloud cover as an exogenous variable did not contributed significantly to explain CWE electricity market prices, therefore this variable was not used. Furthermore, as precipitation would only be fully specified if used in conjunction with reservoir levels, that was, for practical reasons, outside our scope for such a large region being studied.

Following the widespread use of VAR models [64,65], to evaluate electricity market integration (as in Refs. [34,66]), VARX models were estimated. These models allowed separate

\footnotetext{
3 Base temperature of $15.5^{\circ}$ Celsius.

4 Some assumptions were made: perfect wind speed predictions and average wind speed representative for the peak period.
} 
BPX PEAK
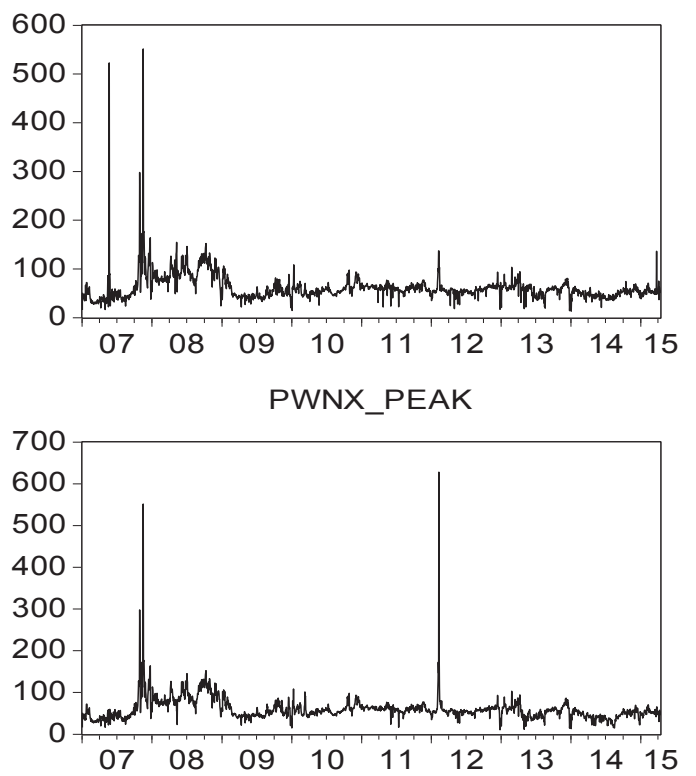

EEX PEAK
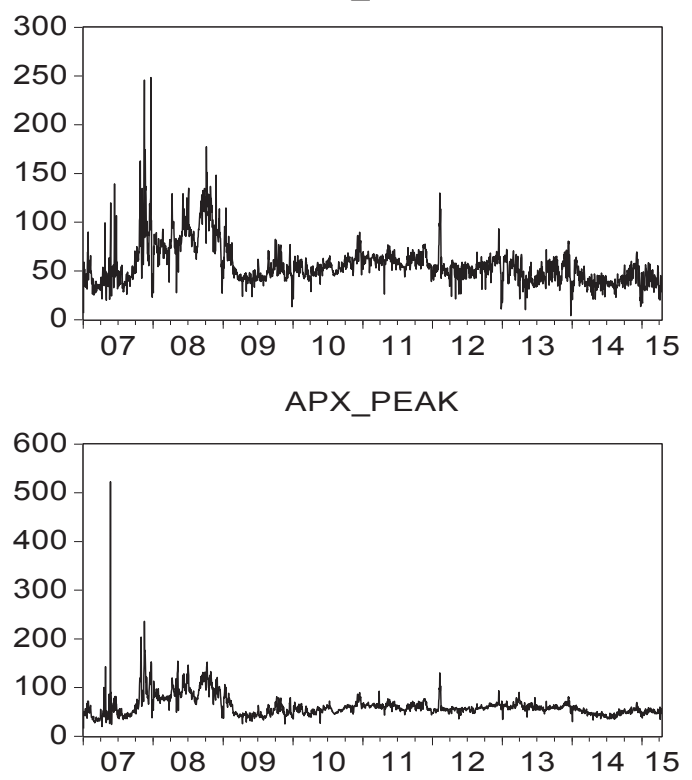

Fig. 4. Day-ahead spot electricity prices in €/MWh (BPX - Belgium, PWNX - France, EEX - Germany, APX - the Netherlands).

Table 2

Model lag length.

\begin{tabular}{|c|c|c|c|c|c|c|c|c|c|}
\hline \multicolumn{4}{|c|}{ VAR peak } & \multicolumn{3}{|c|}{ VARX peak } & \multicolumn{3}{|c|}{ VAR wind chill } \\
\hline Lag length criteria & Lags & SC & HQ & Lags & SC & HQ & Lags & SC & HQ \\
\hline & 2 & 126.5707 & $125.6636^{*}$ & 5 & -4.856887 & $-5.083654^{*}$ & 3 & $34.57369^{*}$ & 34.48436 \\
\hline
\end{tabular}

* indicates lag order selected by the criterion.

contemporaneous and lagged effects of price and weather induced spillovers to be assessed. Since our analysis was not concerned with the intraday effects of weather forecast errors, we used the actual measured daily climate data. Generalised Impulse Response Analysis [67] was finally used to enable an investigation of the overall potential impacts of unexpected shocks or innovations on the endogenous variables.

The most general form of the model, VARX, is as follows:
Godfrey test for residual autocorrelation was performed to all models, indicating adjustment of the number of lags used in each model [64]. Also a lag exclusion Wald test was performed to each model, in order to detect lags with non-significant coefficients [68]. The stability condition of no roots outside the unit circle is satisfied for all equations in the models.

For the first model (VAR Peak), all variables are considered to be endogenous (there were no exogenous variables considered), in order to capture the corresponding inter-relationships, therefore, ${ }^{5}$

$Y_{t}^{T}=\left(B P X_{\text {peak }}, P W N X_{\text {peak }} E E X_{\text {peak }}, A P X_{\text {peak }}, W S_{z} \cdot W \operatorname{Cap}_{z}, H D D_{z}, W S_{z} \cdot H D D_{z}\right)_{t}$

$Y_{t}=C+\sum_{i=1}^{p} A_{i} Y_{t-i}+B X_{t}+u_{t}$

where $Y_{t}$ is the log day-ahead electricity price matrix, $C$ is the constant matrix, $A_{i}$ and $B$ are coefficient matrices, $X_{t}$ is the exogenous variable matrix and $u_{t}$ is the matrix of unobservable error terms. The Schwartz Bayesian criterion (SC) and the Hannan-Quinn criterion (HQ) were used to determine the lag length of each model in a sequential test procedure through successive estimation, starting with 15 lag models and calculating-down for lower lags. The endogenous variable lags where criteria are minimised are presented in Table 2 for the three estimated models. The Breusch-
In the second model (VARX Peak), the price inter-relationships and the influence of wind power, heating degree days and wind chill on prices are captured, therefore, the endogenous variable matrix is $Y_{t}^{T}=\left(B P X_{\text {peak }}, P W N X_{\text {peak }} E E X_{\text {peak }}, A P X_{\text {peak }}\right)_{t}$ and the exogenous variable matrix is $X_{t}^{T}=\left(W S_{z} \cdot W c a p_{z}, H D D_{z}, W S_{z} \cdot H D D_{z}\right)_{t}$. The third model (VAR Wind Chill) intends to capture the interrelationships of wind chill alone, therefore, it only considers as endogenous variables $Y_{t}^{T}=\left(W S_{z} \cdot H D D_{z}\right)_{t}$.

\footnotetext{
${ }^{5}$ where $z$ is the subscript for Belgium, France, Germany and the Netherlands.
} 
Table 3

VARX Wind power generation proxy.

\begin{tabular}{|c|c|c|c|c|}
\hline 2007-2014 & 1_BPX_PEAK & 1_EEX_PEAK & 1_PWNX_PEAK & 1_APX_PEAK \\
\hline BE_WSAVG $\times$ WIND_BE & $\begin{array}{l}0.00000058 \\
{[0.31913]}\end{array}$ & $\begin{array}{l}-0.0000035 \\
{[-1.8557]^{*}}\end{array}$ & $\begin{array}{l}0.00000139 \\
{[0.77677]}\end{array}$ & $\begin{array}{l}0.00000135 \\
{[0.95535]}\end{array}$ \\
\hline DE_WSAVG $\times$ WIND_DE & $\begin{array}{l}-0.0000001 \\
{[-1.04236]}\end{array}$ & $\begin{array}{l}-4.08 \mathrm{E}-07 \\
{[-4.09718]^{* * *}}\end{array}$ & $\begin{array}{l}-1.27 \mathrm{E}-07 \\
{[-1.35185]}\end{array}$ & $\begin{array}{l}-7.98 \mathrm{E}-08 \\
{[-1.06850]}\end{array}$ \\
\hline FR_WSAVG $\times$ WIND_FR & $\begin{array}{l}-0.0000019 \\
{[-2.93603]^{* * *}}\end{array}$ & $\begin{array}{l}-0.00000183 \\
{[-2.73242]^{* * *}}\end{array}$ & $\begin{array}{l}-0.00000199 \\
{[-3.13568]^{* * *}}\end{array}$ & $\begin{array}{l}-0.00000131 \\
{[-2.60477]^{* * *}}\end{array}$ \\
\hline NL_WSAVG $\times$ WIND_NL & $\begin{array}{l}-0.00000178 \\
{[-1.60586]}\end{array}$ & $\begin{array}{l}-0.0000026 \\
{[-2.26355]^{* *}}\end{array}$ & $\begin{array}{l}-0.00000318 \\
{[-2.92881]^{* * *}}\end{array}$ & $\begin{array}{l}-0.00000267 \\
{[-3.10513]^{* * *}}\end{array}$ \\
\hline
\end{tabular}

Significant at ${ }^{* * *} 1 \% * * 5 \% * 10 \%$ significance level.

Vector autoregression estimates standard errors in ( ) \& t-statistics in [ ].

\section{Analysis and discussion of results}

\subsection{Wind effects on demand and supply}

In the estimated models, we use the product of wind speed and installed wind capacity as a proportional proxy for wind power output, and the product of wind speed and Heating Degree-Days as a proxy for the wind-chill effect. The results in Tables 3 and 4 show the relevant coefficients taken from the full VARX modelling:

- Local wind power generation has significant negative effects, as expected, in all four countries. Surprisingly, France and the Netherlands have the most significant negative spillovers into the other countries, whilst Germany and Belgium have no significant effects elsewhere. These are, of course, average effects, but they do suggest that it is not necessarily the case that the largest wind generating country will spread lower prices to its neighbours. Rather a country that is predominantly low cost and results show that all countries have a positive wind-chill relation with their own previous day conditions and that Germany does indeed follow the others. In France, the positive lagged effects are significant for three days, and this is a characteristic of thermal inertia in electric heating systems. Thus, the French price spillover is likely to have a persistent effect on its neighbours.

\subsection{Impulse response analysis}

With contemporaneous price arbitrage within the coupled market and various specific demand and supply side weather influences, the net effect of shocks is the sum of complex interactions. We therefore present the impulse response functions within the full VAR Peak model to give an indication of the overall spillover potential and their persistence.

In Fig. 5, in Appendix B, we see the spillover potential of the

Table 4

VARX Wind chill proxy.

\begin{tabular}{|c|c|c|c|c|}
\hline 2007-2014 & 1_BPX_PEAK & 1_EEX_PEAK & 1_PWNX_PEAK & 1_APX_PEAK \\
\hline BE_WSAVG $\times$ BE_HDD & $\begin{array}{l}-0.000225 \\
{[-0.90849]}\end{array}$ & $\begin{array}{l}0.000209 \\
{[0.81248]}\end{array}$ & $\begin{array}{l}-0.000582 \\
{[-2.39367]^{* *}}\end{array}$ & $\begin{array}{l}-0.000326 \\
{[-1.69385]^{*}}\end{array}$ \\
\hline DE_WSAVG $\times$ DE_HDD & $\begin{array}{l}-0.0000123 \\
{[-0.04603]}\end{array}$ & $\begin{array}{l}0.0000657 \\
{[0.23639]}\end{array}$ & $\begin{array}{l}0.000401 \\
{[1.52524]}\end{array}$ & $\begin{array}{l}-0.00014 \\
{[-0.67098]}\end{array}$ \\
\hline FR_WSAVG $\times$ FR_HDD & $\begin{array}{l}0.001354 \\
{[1.82301]^{*}}\end{array}$ & $\begin{array}{l}0.0013 \\
{[1.68903]^{*}}\end{array}$ & $\begin{array}{l}0.001515 \\
{[2.07892]^{* *}}\end{array}$ & $\begin{array}{l}0.001797 \\
{[3.11189]^{* * *}}\end{array}$ \\
\hline NL_WSAVG $\times$ NL_HDD & $\begin{array}{l}0.0000972 \\
{[0.36224]}\end{array}$ & $\begin{array}{l}-0.000183 \\
{[-0.65896]}\end{array}$ & $\begin{array}{l}0.000229 \\
{[0.86800]}\end{array}$ & $\begin{array}{l}0.000331 \\
{[1.58623]}\end{array}$ \\
\hline
\end{tabular}

Significant at ${ }^{* * *} 1 \% * * 5 \% * 10 \%$ significance level.

Vector autoregression estimates standard errors in ( ) \& t-statistics in [ ].

exporting (France) may be more influential. The Netherlands appears to be both an importer from Germany and an exporter to Belgium, and so even though it is a small wind producer, its price sensitivity is effective. Belgium, as an importer, does not spillover.

- French wind chill has significant positive influence on its own prices, as expected, given the high sensitivity of demand to cold weather in that country. Furthermore, this positive effect spills over to all other CWE markets. Evidently, the increased demand is met not only by the French internal supply, but also by electricity imports from neighbouring countries. Similar wind-chill effects are not observed in the other countries, as they are not associated with such high intensity of electric heating.

- In Table 5 we report endogenous lags to explore the inter-day dynamic spillover of the wind-chill effect. Whilst we expect arbitrage in prices for a coupled market to be contemporaneous, windy weather systems generally move across Europe from West to East. Thus, windy conditions in Belgium, France and the Netherlands would on average precede those in Germany. The wind power proxy on adjacent electricity peak prices. All impacts are initially significant, negative and the persistence to a one standard deviation shock is about four periods. Similarly, Fig. 6 shows the impact of cold weather shocks. These tend to increase prices and are more persistent. The combination of wind speed and cold weather is shown in Fig. 7 in terms of wind-chill. Here, most interestingly, the initial impact is negative (perhaps mainly a supply side effect of wind power) and then positive as the extra heating is required. Finally, for completeness in Fig. 8 we show the endogenous price interactions. Price shocks transmit across the coupled markets and gradually decay, as expected and as noted by other researchers who have investigated these indications of market integration.

\section{Conclusion}

This study was motivated by the observation that the effects of renewable energy output variations across several integrated power markets are likely to be complicated by price arbitrage and 
Table 5

VAR wind chill - sample $1 / 1 / 2007$ to $31 / 12 / 2014-2162$ observations.

\begin{tabular}{|c|c|c|c|c|}
\hline & BE_WSAVG $\times$ BE_HDD & DE_WSAVG $\times$ DE_HDD & FR_WSAVG $\times$ FR_HDD & NL_WSAVG $\times$ NL_HDD \\
\hline BE_WSAVG $(-1) \times$ BE_HDD $(-1)$ & $\begin{array}{l}0.445344 \\
{[14.2342]^{* * *}}\end{array}$ & $\begin{array}{l}0.233903 \\
{[6.82318]^{* * *}}\end{array}$ & $\begin{array}{l}0.036301 \\
{[3.23136]^{* * *}}\end{array}$ & $\begin{array}{l}0.135016 \\
{[3.69104]^{* * *}}\end{array}$ \\
\hline BE_WSAVG $(-2) \times$ BE_HDD $(-2)$ & $\begin{array}{l}0.041359 \\
{[1.25384]}\end{array}$ & $\begin{array}{l}-0.047363 \\
{[-1.31046]}\end{array}$ & $\begin{array}{l}-0.028174 \\
{[-2.37878]^{* *}}\end{array}$ & $\begin{array}{l}-0.018147 \\
{[-0.47053]}\end{array}$ \\
\hline BE_WSAVG $(-3) \times$ BE_HDD $(-3)$ & $\begin{array}{l}0.072713 \\
{[2.30996]^{* *}}\end{array}$ & $\begin{array}{l}-0.01659 \\
{[-0.48100]}\end{array}$ & $\begin{array}{l}0.001843 \\
{[0.16307]}\end{array}$ & $\begin{array}{l}-0.030263 \\
{[-0.82231]}\end{array}$ \\
\hline DE_WSAVG $(-1) \times$ DE_HDD $(-1)$ & $\begin{array}{l}0.028281 \\
{[1.15155]}\end{array}$ & $\begin{array}{l}0.37225 \\
{[13.8339]^{* * *}}\end{array}$ & $\begin{array}{l}-0.008171 \\
{[-0.92663]}\end{array}$ & $\begin{array}{l}-0.009178 \\
{[-0.31965]}\end{array}$ \\
\hline DE_WSAVG $(-2) \times$ DE_HDD $(-2)$ & $\begin{array}{l}0.035526 \\
{[1.36558]}\end{array}$ & $\begin{array}{l}0.009246 \\
{[0.32435]}\end{array}$ & $\begin{array}{l}0.035975 \\
{[3.85123]^{* * *}}\end{array}$ & $\begin{array}{l}0.053624 \\
{[1.76299]^{*}}\end{array}$ \\
\hline $\operatorname{DE} \_W S A V G(-3) \times$ DE_HDD $(-3)$ & $\begin{array}{l}0.089132 \\
{[3.68756]^{* * *}}\end{array}$ & $\begin{array}{l}0.165917 \\
{[6.26481]^{* * *}}\end{array}$ & $\begin{array}{l}0.007541 \\
{[0.86887]}\end{array}$ & $\begin{array}{l}0.046121 \\
{[1.63204]}\end{array}$ \\
\hline FR_WSAVG $(-1) \times$ FR_HDD $(-1)$ & $\begin{array}{l}0.168532 \\
{[2.6338]^{* * *}}\end{array}$ & $\begin{array}{l}0.15751 \\
{[2.24658]^{* *}}\end{array}$ & $\begin{array}{l}0.342332 \\
{[14.8999]^{* * *}}\end{array}$ & $\begin{array}{l}0.197716 \\
{[2.64284]^{* * *}}\end{array}$ \\
\hline FR_WSAVG $(-2) \times$ FR_HDD $(-2)$ & $\begin{array}{l}0.075434 \\
{[1.13202]}\end{array}$ & $\begin{array}{l}0.155153 \\
{[2.12499]^{* *}}\end{array}$ & $\begin{array}{l}0.129872 \\
{[5.42792]^{* * *}}\end{array}$ & $\begin{array}{l}0.160178 \\
{[2.05596]^{* *}}\end{array}$ \\
\hline FR_WSAVG $(-3) \times$ FR_HDD $(-3)$ & $\begin{array}{l}0.159352 \\
{[2.50324]^{* *}}\end{array}$ & $\begin{array}{l}0.093759 \\
{[1.34422]}\end{array}$ & $\begin{array}{l}0.109908 \\
{[4.80846]^{* * *}}\end{array}$ & $\begin{array}{l}0.163032 \\
{[2.19051]^{* *}}\end{array}$ \\
\hline NL_WSAVG $(-1) \times \mathrm{NL} \_H D D(-1)$ & $\begin{array}{l}0.091282 \\
{[3.69991]^{* * *}}\end{array}$ & $\begin{array}{l}0.054973 \\
{[2.03362]^{* *}}\end{array}$ & $\begin{array}{l}0.023332 \\
{[2.63381]^{* * *}}\end{array}$ & $\begin{array}{l}0.369898 \\
{[12.8237]^{* * *}}\end{array}$ \\
\hline NL_WSAVG $(-2) \times$ NL_HDD $(-2)$ & $\begin{array}{l}-0.013619 \\
{[-0.53114]}\end{array}$ & $\begin{array}{l}-0.02728 \\
{[-0.97096]}\end{array}$ & $\begin{array}{l}0.012772 \\
{[1.38721]}\end{array}$ & $\begin{array}{l}0.091357 \\
{[3.04732]^{* * *}}\end{array}$ \\
\hline NL_WSAVG $(-3) \times$ NL_HDD $(-3)$ & $\begin{array}{l}-0.019173 \\
{[-0.77706]}\end{array}$ & $\begin{array}{l}0.017645 \\
{[0.65267]}\end{array}$ & $\begin{array}{l}0.000371 \\
{[0.04190]}\end{array}$ & $\begin{array}{l}0.109072 \\
{[3.78089]^{* * *}}\end{array}$ \\
\hline C & $\begin{array}{l}3.767092 \\
{[4.82796]^{* * *}}\end{array}$ & $\begin{array}{l}4.048953 \\
{[4.73602]^{* * *}}\end{array}$ & $\begin{array}{l}1.329848 \\
{[4.74671]^{* * *}}\end{array}$ & $\begin{array}{l}4.032492 \\
{[4.42036]^{* * *}}\end{array}$ \\
\hline R-squared & 0.623337 & 0.581325 & 0.50175 & 0.564083 \\
\hline Adj. R-squared & 0.621156 & 0.5789 & 0.498864 & 0.561559 \\
\hline Schwarz SC & 9.292424 & 9.475189 & 7.243893 & 9.604993 \\
\hline
\end{tabular}

Significant at ${ }^{* * *} 1 \% * * 5 \% * 10 \%$ significance level.

Vector autoregression estimates standard errors in ( ) \& t-statistics in [ ].

weather dynamics. Wind in particular has supply side effects when associated with substantial generating facilities, but also demand side influences when associated with cold weather. This means that assessing the specific effects of weather conditions on various markets, e.g. for operational prediction or hedging, may require subtle analysis. Through detailed modelling of the Central West Europe coupled market comprising Belgium, France, Germany and the Netherlands, we found that despite efficient price arbitrage, it is not the case that daily wind power output shocks diffuse uniformly across all markets, or that the largest generator of wind energy creates the most significant spillovers or that high wind conditions necessarily lead to lower prices.

Furthermore, whereas simple scatter diagrams appear to suggest very little relationship between cross-border energy flows and wind production in these countries (Fig. 3), impulse response analysis from a large vector autoregression with endogenous and exogenous representations of price and weather variables indicated the potential for mutual spillovers across all countries. However, specific analyses of the coefficients of selected variables in the VAR revealed idiosyncratic characteristics. Whereas Germany was by far the largest energy market and the largest generator of wind energy, it also tended to import substantially from France (Fig. 2) and had a flat supply function dominated in its mid-range by coal facilities (Fig. 1). Thus, whilst neighbouring wind generation may be highly correlated (Roques et al., 2010 [69], reported a correlation of 0.4 for France and Germany), on average, Germany did not appear to spillover wind-induced price effects to its neighbours. This more extensive modelling thereby reverses some of the conventional indications suggested elsewhere, e.g. Ref. [70]. Alternatively, France, being a low cost exporter, even with much less wind generation, had, on average, significant spillover effects in lowering prices for all neighbours when its wind output increased. Furthermore, France has substantially higher price response to demand, because of widespread electrical heating, and when wind conditions combine with cold weather to produce a wind chill effect, higher prices emerge and spillover to all neighbours. We also found that a smaller importing country such a Belgium created little spillover, but a similar smaller country like the Netherlands, being a transit between imports from Germany and exports to Belgium, proved to have a very sensitive effect on price spillovers if its wind production changed. Finally, the dynamics of the weather induced effects on demand and, as a consequence, on prices were longer lasting, as weather conditions moved across the countries, than the supply side effects.

Overall, apart from market harmonisation and interconnector capacities, understanding the arbitrage dynamics of prices as more renewable energies enter the production mix requires rather specific unravelling of the supply-side and demand-side specificities of the countries involved. The relative slopes of the supply functions around demand levels are important, as well as the technology mix and possible market power effects determining the price spreads. The nature and regional dynamics of demand also requires careful analysis, as demand-side effects may significantly counteract the supply side. As a basis for analysis however, vector autoregression is useful and could well support weather risk models, although it appears to require large scale specification. We did not, however, undertake an intraday hourly panel representation, as our specification was already large in terms of lags, prices and weather variables, but it is likely that for operational precision, intraday granularity will be required in practice.

\section{Acknowledgements}

This work has been framed under the Energy for Sustainability Initiative of the University of Coimbra and partially supported by the Portuguese Foundation for Science and Technology under project grant UID/MULTI/00308/2013. 


\section{Appendix A}

Table 6

Essential weather variables for demand forecasting.

\begin{tabular}{|c|c|c|}
\hline $\begin{array}{l}\text { Weather exogenous } \\
\text { variables }\end{array}$ & $\begin{array}{l}\text { Weather ensembles - European Centre for medium- electricity demand forecasting. The range of different range weather } \\
\text { forecasts (ECMWF) }\end{array}$ & [8] \\
\hline \multirow[t]{4}{*}{ Ambient temperature } & Avg. Amb. Temp. & {$[4-8,11,19]$} \\
\hline & Max. Amb. Temp. & {$[2,3]$} \\
\hline & Min. Amb. Temp. & [2] \\
\hline & Cooling and heating degree days & {$[3,7,9,10]$} \\
\hline \multirow[t]{3}{*}{ Relative humidity } & Avg. Rel. Hum. & {$[3,4,7,8,10]$} \\
\hline & Max. Rel. Hum. & [3] \\
\hline & Enthalpy latent days & [7] \\
\hline Precipitation & & [8] \\
\hline Wind Speed & & $\begin{array}{l}{[3,7,8,26} \\
-29]\end{array}$ \\
\hline \multirow[t]{3}{*}{ Solar } & Cloud cover & [8] \\
\hline & Sunshine duration & [3] \\
\hline & Global radiation & [3] \\
\hline Comfort index & & [3] \\
\hline $\begin{array}{l}\text { Weather exogenous } \\
\text { variables }\end{array}$ & $\begin{array}{l}\text { Weather ensembles - European Centre for Medium- electricity demand forecasting. The range of different range Weather } \\
\text { Forecasts (ECMWF) }\end{array}$ & [8] \\
\hline
\end{tabular}

\section{Appendix B}

Response to Generalized One S.D. Innovations \pm 2 S.E.
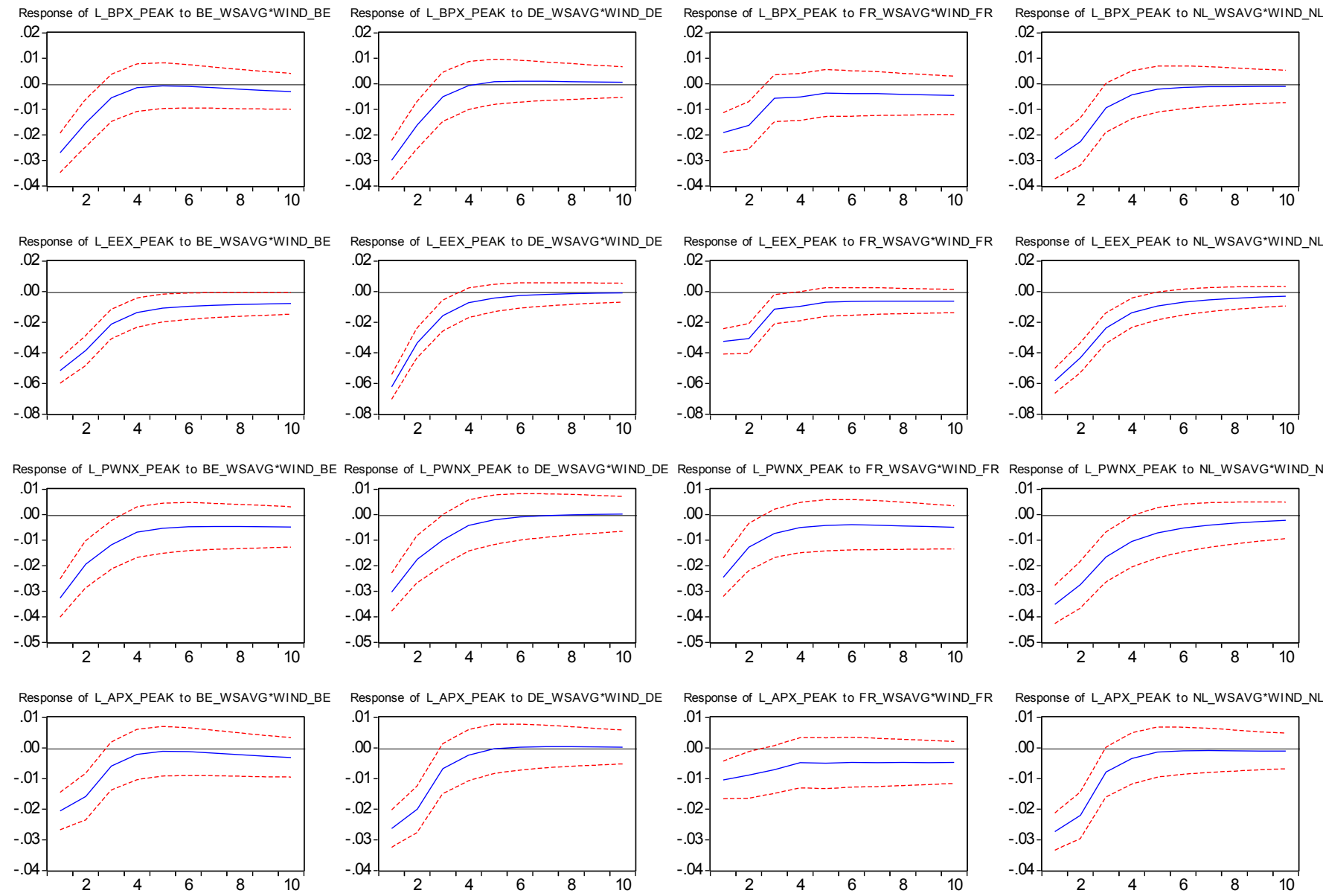

Fig. 5. Impulse response functions of peak spot electricity prices to wind power proxy shocks. 
Response to Generalized One S.D. Innovations \pm 2 S.E.
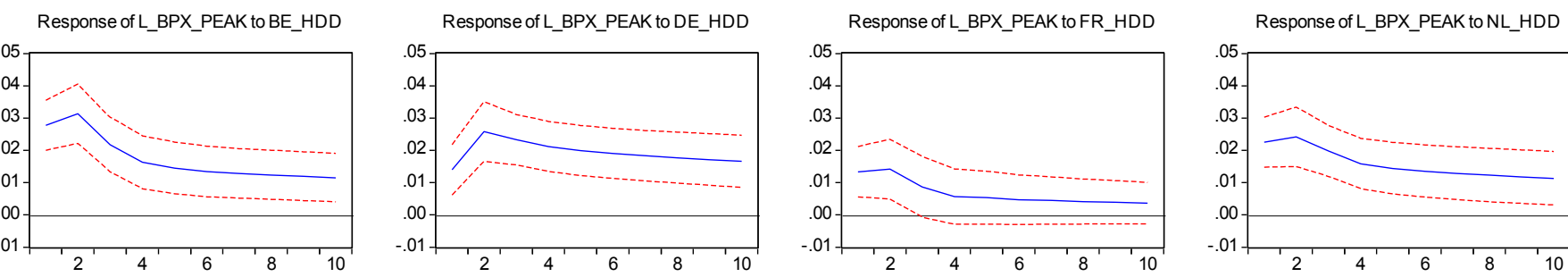

Response of L_EEX_PEAK to BE_HDD
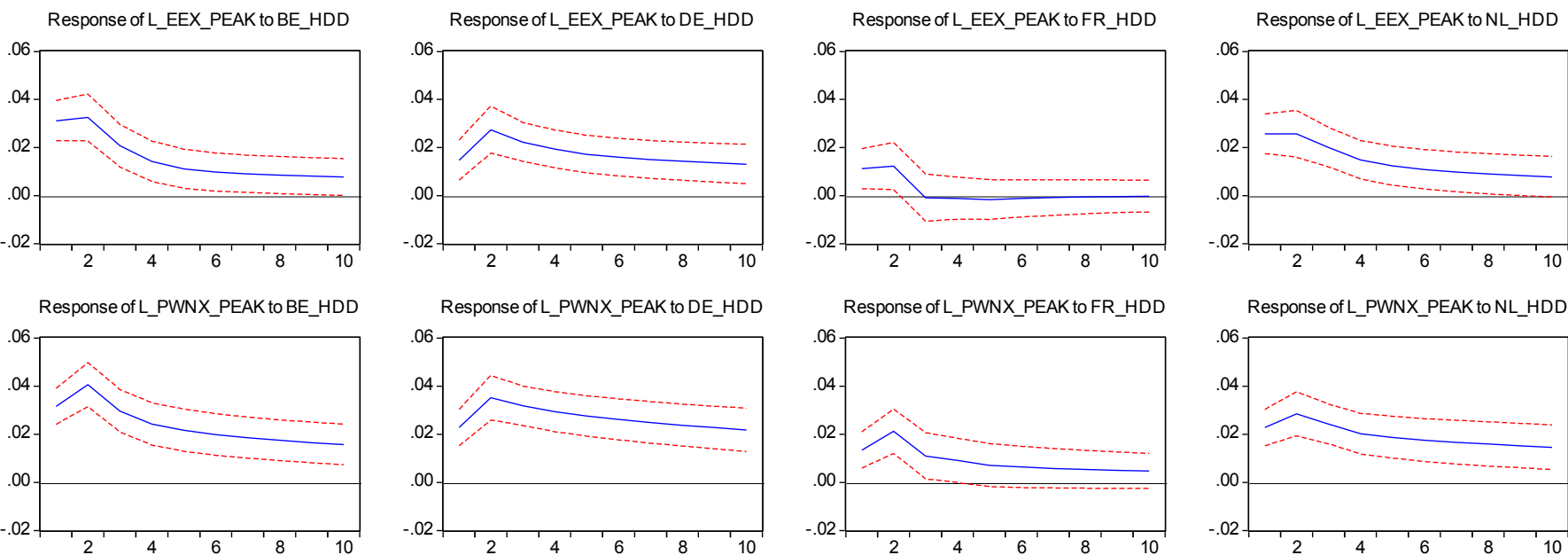

Response of L_PWNX_PEAK to NL_HDD
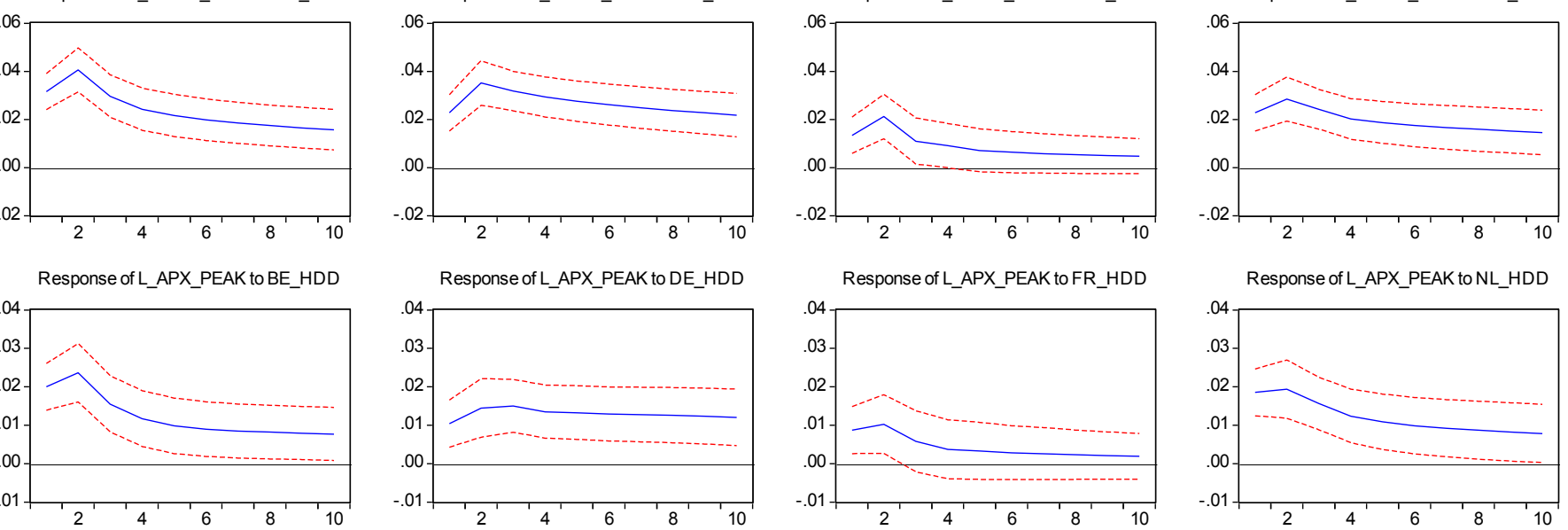

Fig. 6. Impulse response functions of peak spot electricity prices to HDD shocks. 
Response to Generalized One S.D. Innovations \pm 2 S.E.
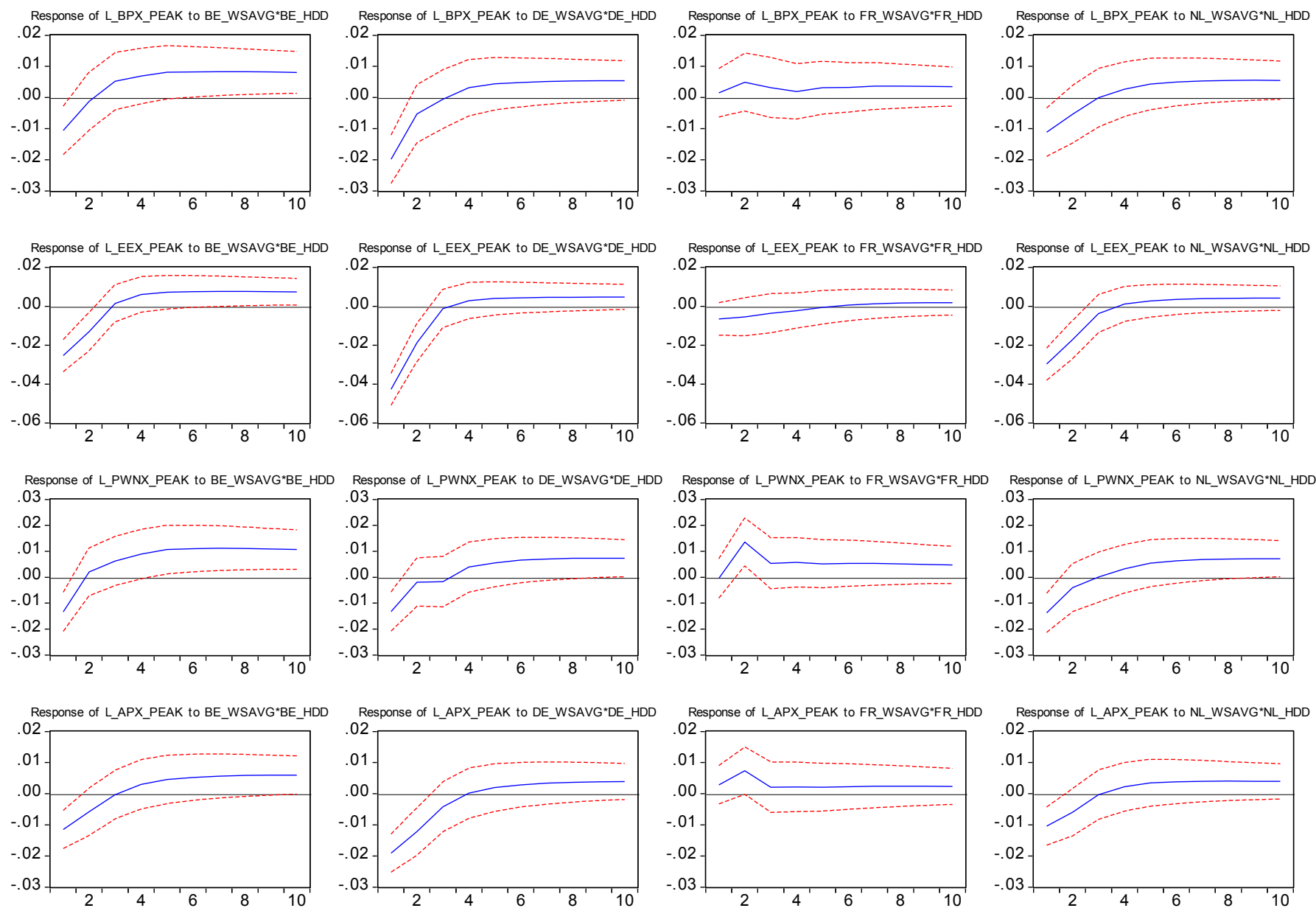

Fig. 7. Impulse response functions of peak spot electricity prices to wind chill proxy shocks. 
Response to Generalized One S.D. Innovations \pm 2 S.E.
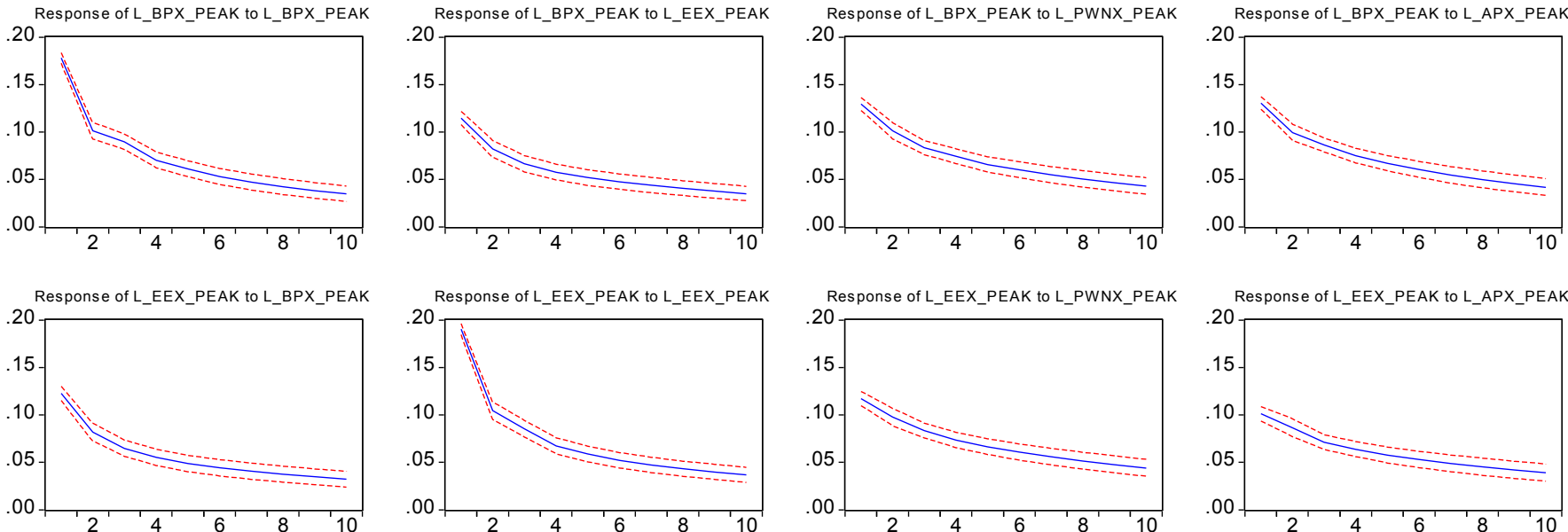

Response of L_PWNX_PEAK to L_BPX_PEAK

Response of L_PWNX_PEAK to L_EEX_PEAK

Response of L_PWNX_PEAK to L_PWNX_PEAK
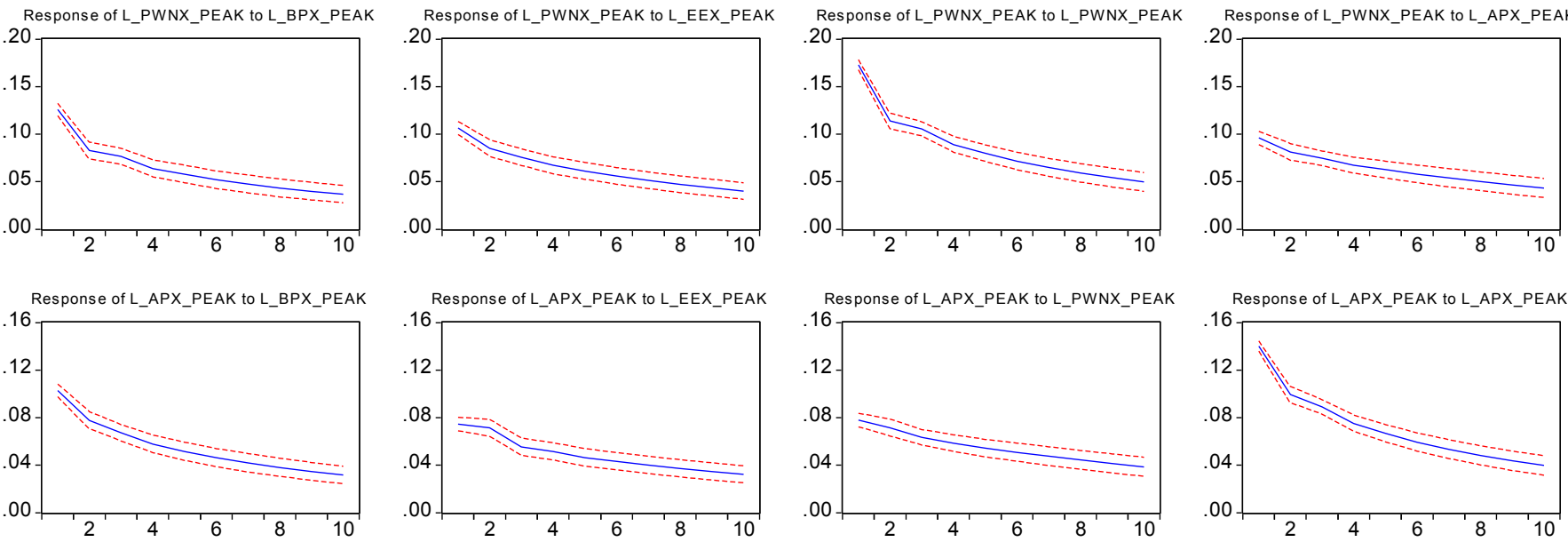

Fig. 8. Impulse response functions of peak spot electricity prices to price shocks. 


\section{References}

[1] ENTSO-E. Scenario outlook \& adequacy forecast. 2015.

[2] Sforna M. Searching for the electric load-weather temperature function by using the group method of data handling. Electr Power Syst Res 1995;32:1-9. http://dx.doi.org/10.1016/0378-7796(94)00891-7.

[3] Islam SM, Al-Alawi SM, Ellithy $\mathrm{K}$ a. Forecasting monthly electric load and energy for a fast growing utility using an artificial neural network. Electr Power Syst Res 1995;34:1-9. http://dx.doi.org/10.1016/0378-7796(95) 00950-M.

[4] Santos PJ, Martins a G, Pires a J. Designing the input vector to ANN-based models for short-term load forecast in electricity distribution systems. Int J Electr Power Energy Syst 2007;29:338-47. http://dx.doi.org/10.1016| j.ijepes.2006.09.002.

[5] Amjady N, Keynia F. Short-term load forecasting of power systems by combination of wavelet transform and neuro-evolutionary algorithm. Energy 2009;34:46-57. http://dx.doi.org/10.1016/j.energy.2008.09.020.

[6] Robinson PJ. Modeling utility load and temperature relationships for use with long-lead forecasts. J Appl Meteorol 1997;36:591-8. http://dx.doi.org/ 10.1175/1520-0450(1997)036<0591:MULATR>2.0.CO;2.

[7] Sailor DJ, Muñoz JR. Sensitivity of electricity and natural gas consumption to climate in the U.S.A. - methodology and results for eight states. Energy 1997;22:987-98. http://dx.doi.org/10.1016/S0360-5442(97)00034-0.

[8] Taylor JW. Using weather ensemble predictions in electricity demand forecasting using weather ensemble predictions in electricity demand forecasting. Int J Forecast 2003;19:57-70.

[9] Pardo A, Meneu V, Valor E. Temperature and seasonality influences on Spanish electricity load. Energy Econ 2002;24:55-70. http://dx.doi.org/10.1016/ S0140-9883(01)00082-2.

[10] Mirasgedis S, Sarafidis Y, Georgopoulou E, Lalas DP, Moschovits M, Karagiannis F, et al. Models for mid-term electricity demand forecasting incorporating weather influences. Energy 2006;31:208-27. http://dx.doi.org/ 10.1016/j.energy.2005.02.016.

[11] Bessec M, Fouquau J. The non-linear link between electricity consumption and temperature in Europe: a threshold panel approach. Energy Econ 2008;30: 2705-21. http://dx.doi.org/10.1016/j.eneco.2008.02.003.

[12] Suganthi L, Samuel A a. Energy models for demand forecasting - a review. Renew Sustain Energy Rev 2012;16:1223-40. http://dx.doi.org/10.1016 j.rser.2011.08.014.

[13] De Felice M, Alessandri A, Ruti PM. Electricity demand forecasting over Italy: potential benefits using numerical weather prediction models. Electr Power Syst Res 2013;104:71-9. http://dx.doi.org/10.1016/j.epsr.2013.06.004.

[14] Karakatsani NV, Bunn DW. Intra-day and regime-switching dynamics in electricity price formation. Energy Econ 2008;30:1776-97. http://dx.doi.org/ 10.1016/j.eneco.2008.02.004.

[15] Bordignon S, Bunn DW, Lisi F, Nan F. Combining day-ahead forecasts for British electricity prices. Energy Econ 2013;35:88-103. http://dx.doi.org/ 10.1016/j.eneco.2011.12.001.

[16] Gianfreda A, Grossi L. Forecasting Italian electricity zonal prices with exogenous variables. Energy Econ 2012;34:2228-39. http://dx.doi.org/10.1016 j.eneco.2012.06.024.

[17] Karakatsani NV, Bunn DW. Forecasting electricity prices: the impact of fundamentals and time-varying coefficients. Int J Forecast 2008;24:764-85. http://dx.doi.org/10.1016/j.ijforecast.2008.09.008.

[18] Wu L, Shahidehpour M. A hybrid model for day-ahead price forecasting constants. Power 2010;25:1519-30.

[19] Weron R, Misiorek A. Forecasting spot electricity prices: a comparison of parametric and semiparametric time series models. Int J Forecast 2008;24: 744-63. http://dx.doi.org/10.1016/j.ijforecast.2008.08.004.

[20] Higgs H. Modelling spot prices in deregulated wholesale electricity Markets: a selected empirical review. 2008.

[21] Aggarwal SK, Saini LM, Kumar A. Electricity price forecasting in deregulated markets: a review and evaluation. Int J Electr Power Energy Syst 2009;31: 13-22. http://dx.doi.org/10.1016/j.ijepes.2008.09.003.

[22] Weron R. Electricity price forecasting: a review of the state-of-the-art with a look into the future. Int J Forecast 2014;30:1030-81. http://dx.doi.org 10.1016/j.ijforecast.2014.08.008.

[23] Higgs $\mathrm{H}$, Worthington A. Stochastic price modeling of high volatility, meanreverting, spike-prone commodities: the Australian wholesale spot electricity market. Energy Econ 2008;30:3172-85. http://dx.doi.org/10.1016/ j.eneco.2008.04.006.

[24] Christensen TM, Hurn a S, Lindsay K a. Forecasting spikes in electricity prices. Int J Forecast 2012;28:400-11. http://dx.doi.org/10.1016 j.ijforecast.2011.02.019.

[25] Zachmann G. A stochastic fuel switching model for electricity prices. Energy Econ 2013;35:5-13. http://dx.doi.org/10.1016/j.eneco.2012.06.019.

[26] Cruz A, Muñoz A, Zamora JL, Espínola R. The effect of wind generation and weekday on Spanish electricity spot price forecasting. Electr Power Syst Res 2011;81:1924-35. http://dx.doi.org/10.1016/j.epsr.2011.06.002.

[27] Jónsson T, Pinson P, Nielsen HA, Madsen H, Nielsen TS. Forecasting electricity spot prices accounting for wind power predictions. IEEE Trans Sustain Energy 2013;4:210-8. http://dx.doi.org/10.1109/TSTE.2012.2212731.

[28] Ziel F, Steinert R, Husmann S. Efficient modeling and forecasting of electricity spot prices. Energy Econ 2015;47:98-111. http://dx.doi.org/10.1016/ j.eneco.2014.10.012.

[29] Keles D, Genoese M, Möst D, Ortlieb S, Fichtner W. A combined modeling approach for wind power feed-in and electricity spot prices. Energy Policy 2013;59:213-25. http://dx.doi.org/10.1016/j.enpol.2013.03.028.

[30] De Vany AS, Walls WD. Cointegration analysis of spot electricity prices: insights on transmission efficiency in the western US. Energy Econ 1999;21: 435-48. http://dx.doi.org/10.1016/S0140-9883(99)00019-5.

[31] Park H, Mjelde JW, Bessler D a. Price dynamics among U.S. electricity spot markets. Energy Econ 2006;28:81-101. http://dx.doi.org/10.1016/ j.eneco.2005.09.009.

[32] Worthington A, Kay-Spratley A, Higgs H. Transmission of prices and price volatility in Australian electricity spot markets: a multivariate GARCH analysis. Energy Econ 2005;27:337-50. http://dx.doi.org/10.1016/ j.eneco.2003.11.002.

[33] Higgs H. Modelling price and volatility inter-relationships in the Australian wholesale spot electricity markets. Energy Econ 2009;31:748-56. http:// dx.doi.org/10.1016/j.eneco.2009.05.003.

[34] Bunn DW, Gianfreda A. Integration and shock transmissions across European electricity forward markets. Energy Econ 2010;32:278-91. http://dx.doi.org/ 10.1016/j.eneco.2009.09.005.

[35] Figueiredo NC, Silva PP da. Integration of Central West Europe spot electricity markets: an update. In: 2013 10th Int. Conf. Eur. Energy Mark. IEEE; 2013. p. 1-7. http://dx.doi.org/10.1109/EEM.2013.6607299.

[36] European Union. Directive 90/547/EEC of 29 October 1990 on the transit of electricity through transmission grids. Off J Eur Commun 1990;L 313:30-3.

[37] European Union. Directive 90/377/EEC of 29 June 1990 concerning a community procedure to improve the transparency of gas and electricity prices charged to industrial end-users. Off J Eur Commun 1990;L 185:16-24.

[38] European Union. Directive 2003/54/EC of the European Parliament and of the council of 26 June 2003 concerning common rules for the internal market in electricity and repealing Directive 96/92/EC. Off J Eur Union 2003;L 176: 37-56.

[39] European Union. Directive 2009/72/EC of the European Parliament and of the council of 13 July 2009 concerning common rules for the internal market in electricity and repealing Directive 2003/54/EC. Off J Eur Union 2009; L 211: 55-93.

[40] Banovac E, Glavic M, Tesnjak S. Establishing an efficient regulatory mechanism-Prerequisite for successful energy activities regulation. Energy 2009;34:178-89. http://dx.doi.org/10.1016/j.energy.2008.10.002.

[41] Coppens F, Vivet D. The single European electricity Market: a long road to convergence. 2006.

[42] Karova R. Regional electricity markets in Europe: focus on the energy community. Util Policy 2011;19:80-6. http://dx.doi.org/10.1016/ j.jup.2010.10.001.

[43] Meeus L, Belmans R. Electricity market integration in Europe. Conf Proc 16th Power Syst Comput Conf Glas Scotl 2008:1-5.

[44] ENTSO-E. Indicative values for net transfer capacities (NTC) in continental Europe 2011:1. https://www.entsoe.eu/publications/market-and-rd-reports/ ntc-values/ntc-matrix/ (accessed 18.01.13.).

[45] European Commission. Eu energy in figures - statistical pocketbook 20122012. Luxembourg: Publications Office of the European Union; 2012. http://dx.doi.org/10.2833/11169.

[46] European Union. Directive 2009/28/EC of the European Parliament and of the Council of 23 April 2009 on the promotion of the use of energy from renewable sources and amending and subsequently repealing Directives 2001/77/EC and 2003/30/EC. Off J Eur Union 2009;L140:16-62.

[47] European Union. Directive 2001/77/EC of the European Parliament and of the Council of 27 September 2001 on the promotion of electricity produced from renewable energy sources in the internal electricity market. Off J Eur Commun 2001;L283:33-40.

[48] Meyer NI. European schemes for promoting renewables in liberalised markets. Energy Policy 2003;31:665-76. http://dx.doi.org/10.1016/S03014215(02)00151-9.

[49] Jager D de, Klessmann C, Stricker E, Winkel T, Visser E de, Koper M, et al. Financing renewable energy in the European energy market. Ecofys Report. 2011:1-264. http://ec.europa.eu/energy/renewables/studies/doc/renewables/ 2011_financing_renewable.pdf (accessed 09.05. 12).

[50] Amorim F, Vasconcelos J, Abreu IC, da Silva PP, Martins V. How much room for a competitive electricity generation market in Portugal? Renew Sustain Energy Rev 2013;18:103-18. http://dx.doi.org/10.1016/j.rser.2012.10.010.

[51] Eurostat. Eurostat - database. 2015. http://ec.europa.eu/eurostat/data/ database (accessed 06.03.15).

[52] Würzburg K, Labandeira X, Linares P. Renewable generation and electricity prices: taking stock and new evidence for Germany and Austria. Energy Econ 2013;40. http://dx.doi.org/10.1016/j.eneco.2013.09.011. Supple:S159-71.

[53] 2009 review. Report, energy policies IEA ctries. France: IEA; 2009. p. 1-160.

[54] ENTSO-e transparency platform. Entso-E; 2015. https://transparency.entsoe. eu/ (accessed 22.04.15).

[55] Datastream. Thomson Reuters Datastream; 2015.

[56] Goto M, Karolyi GA. Understanding electricity price volatility within and across markets, 2004-12; 2004.

[57] Hadsell L, Marathe A, Shawky H a. Estimating the volatility of wholesale electricity spot prices in the US. Energy J 2004;25:23-40. http://dx.doi.org/ 10.5547/ISSN0195-6574-EJ-Vol25-No4-2.

[58] da Silva PP, Soares I. EU spot prices and industry structure: assessing 
electricity market integration. Int J Energy Sect Manag 2008;2:340-50. http:/| dx.doi.org/10.1108/17506220810892919.

[59] Boisseleau F. The role of power exchanges for the creation of a single European electricity market: market design and market regulation. Univ Paris IX Dauphine 2004:1-405.

[60] Weather wunderground. Weather Underground; 2015. www.wunderground. com.

[61] Mourshed M. Relationship between annual mean temperature and degreedays. Energy Build 2012;54:418-25. http://dx.doi.org/10.1016/ j.enbuild.2012.07.024.

[62] UK Climate Projections. How have cooling degree days (CDD) and heating degree days (HDD) been calculated in UKCP09? - crown copyright 2013. 2009. http://ukclimateprojections.defra.gov.uk/22715 (accessed 10.06.13.).

[63] Figueiredo NC, da Silva PP. Explanatory variables on Central-West spot electricity markets integration. Sustain Cities Des People Planet 2013;2013:1-15. Conf. Proceedings, Energy Sustain.

[64] Lütkepohl H. New introduction to multiple time series analysis. Springer;
2005.

65] Sims CA. Macroeconomics and reality. Econometrica 1980;48:1-48.

[66] Freitas CJP, da Silva PP. Evaluation of dynamic pass-through of carbon prices into electricity prices - a cointegrated VECM analysis. Int J Public Pol 2013;9: 65-85. http://dx.doi.org/10.1504/IJPP.2013.053440.

[67] Pesaran HH, Shin Y. Generalized impulse response analysis in linear multivariate models. Econ Lett 1998;58:17-29. http://dx.doi.org/10.1016/S01651765(97)00214-0.

[68] Davidson R, Mackinnon JG. Econometric theory and methods. Illustrate. Oxford University Press; 2004.

[69] Roques F, Hiroux C, Saguan M. Optimal wind power deployment in Europe-a portfolio approach. Energy Policy 2010;38:3245-56. http://dx.doi.org 10.1016/j.enpol.2009.07.048.

[70] Phan S, Roques F. Is the depressive effect of renewables on power prices contagious? a cross border econometric analysis. CEEM Work Pap 2015-16 2015:1-20. 